\title{
Class IA Phosphatidylinositol 3-Kinase Inhibition Inhibits Cell Growth and Proliferation in Mantle Cell Lymphoma
}

\author{
Yoko Tabe $^{a}$ Linhua Jin $^{a}$ Marina Konoplevad ${ }^{d}$ Masato Shikami ${ }^{c}$ \\ Shinya Kimura ${ }^{b}$ Michael Andreeff ${ }^{d}$ Mark Raffeld ${ }^{e}$ Takashi Miida ${ }^{a}$ \\ ${ }^{a}$ Department of Clinical Laboratory Medicine, Juntendo University School of Medicine, Tokyo, ${ }^{b}$ Division of \\ Hematology, Respiratory Medicine and Oncology, Department of Internal Medicine, Faculty of Medicine, \\ Saga University, Honjo-machi, and 'Department of Hematology, Aichi Medical University, Aichi, Japan; \\ ${ }^{\mathrm{d}}$ Department of Leukemia, MD Anderson Cancer Center, The University of Texas, Houston, Tex., and \\ e Molecular Diagnostics Section, Laboratory of Pathology, National Cancer Institute, Bethesda, Md., USA
}

\section{Key Words}

Akt $\cdot$ BCR signaling $\cdot$ Class IA phosphatidylinositol 3-kinase · Mantle cell lymphoma

\begin{abstract}
Background/Aims: Constitutive activation of the phosphatidylinositol 3-kinase (PI3K)/Akt/mammalian target of rapamycin signaling pathway preferentially occurs in aggressive blastoid variants of mantle cell lymphoma (MCL) and is implicated in the pathogenesis of this disease. In this study, we investigated the role of PI3K isoforms on proliferation of aggressive MCL cells. Methods: The changes in cell viability, cell cycle distribution and apoptosis induction by the PI3K isoform-selective inhibitors were evaluated. The molecular basis underlying the effects of the specific inhibition of PI3K isoforms was investigated by Western blot analysis. Results: Our results demonstrated that a class IA PI3K isoform is most commonly involved in the constitutive activation of Akt in aggressive MCL. Treatment with a p110a isoform-specific inhibitor induced prominent cell cycle arrest followed by apoptosis through complete abolishment of phosphorylated (p)-Akt and its downstream targets. An inhibitor of isoform $\mathrm{p} 110 \delta$ induced moderate cell cycle arrest with down-
\end{abstract}

regulation of $\mathrm{p}-\mathrm{Akt}$ and $\mathrm{p}-\mathrm{S} 6 \mathrm{~K}$. A dual inhibitor of $\mathrm{p} 110 \mathrm{a}$ and p1108 GDC-0941 caused more prominent cell growth inhibition compared to selective $\mathrm{p} 110 \mathrm{a}$ or $\mathrm{p} 110 \delta$ inhibitors. Inhibition of the class IB PI3K isoform $\mathrm{p} 110 \mathrm{y}$ did not cause cell cycle arrest or induce apoptosis in MCL cells. Conclusion: These findings suggest that the therapeutic ablation of class IA $\mathrm{PI} 3 \mathrm{~K}$ may be a promising strategy for the treatment of refractory, aggressive MCL.

Copyright $\odot 2013$ S. Karger AG, Basel

\section{Introduction}

Mantle cell lymphoma (MCL) is a subtype of B-cell non-Hodgkin lymphoma characterized by aggressive clinical behavior and, frequently, resistance to chemotherapeutic agents [1]. More than 95\% of MCLs show the $t(11,14)$ (q13;32) translocation, which leads to overexpression of cyclin D1 [2]. Although deregulation of the cyclin $\mathrm{D} 1 /$ retinoblastoma protein $(\mathrm{Rb})$ pathway results in instability of the $G_{1} / S$ checkpoint [2], overexpression of cyclin D1 alone is not sufficient for the development of MCL, and additional genetic events appear to be necessary for oncogenesis [3]. 
It has been demonstrated that constitutive activation of the phosphatidylinositol 3-kinase (PI3K)/Akt/mammalian target of rapamycin (mTOR) pathway plays a critical role in the pathogenesis of aggressive blastoid variants of MCL $[4,5]$. Promising results from several phase II and III trials of the PI3K/Akt/mTOR inhibitor temsirolimus (CCI-779) in relapsed or refractory MCL provide further clinical evidence of the importance of this pathway in MCL [6]. PI3K is the major activator of Akt, a serine/threonine protein kinase that modulates a variety of downstream substrates involved in the regulation of cell cycle progression, cell survival, and transcription. PI3Ks are divided into three classes, class I, II, and III, and only the class I PI3Ks are able to generate the second messenger phosphatidylinositol 3,4,5-trisphosphate through activation of phosphoinositide-dependent kinase-1, which subsequently phosphorylates and activates Akt [7]. Class I PI3Ks are further classified into subclasses IA and IB. Class IA PI3Ks, namely PI3Ka, PI3K $\beta$, and PI $3 K \delta$, are composed of catalytic subunits p110a, p110 $\beta$, and

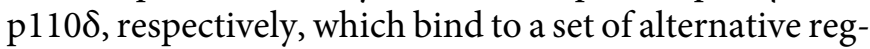
ulatory subunits (including p85a, p85 $\beta$, p $55 \alpha$, p $50 \alpha$, and $\mathrm{p} 55 \gamma$ ) and are activated by receptor tyrosine kinases and Ras [8]. In contrast to $\mathrm{p} 110 \alpha$ and $\mathrm{p} 110 \beta$, which have wide tissue distribution, p110 $\delta$ is expressed mainly in leukocytes [9].

$\mathrm{PI} 3 \mathrm{~K} \delta$ has a dominant role in $\mathrm{B}$-cell responses initiated by antigen-mediated clustering of the B-cell receptor (BCR) via selective recruitment of $\mathrm{p} 110 \delta$ and sequential activation of its downstream pathways $[10,11]$. However, in ligand-independent 'tonic signaling', $\mathrm{p} 110 \alpha$ seems to perform redundant functions for signaling activation, and both PI3Ka and PI3K $\delta$ isoforms have been implicated as mediators of agonist-independent constitutive BCR/PI3K/Akt signaling [11]. We have demonstrated that constitutive activation of the PI3K/Akt pathway occurs preferentially in aggressive blastoid variants but not in typical MCL [5]. In addition to its role in BCR signaling, the p110a isoform plays a particularly important role in tumorigenesis through both gene amplification and gain-of-function mutations [12]. The class IA PI3K isoform $\mathrm{p} 110 \beta$ is known to contribute to tumorigenesis, associating with phosphatidylinositol 3,4,5-trisphosphate production induced by deficiency in PTEN [13], a catalytic antagonist of PI3K [7]. The class IB PI3K $\gamma$, with its catalytic subunit $\mathrm{p} 110 \gamma$ and regulatory subunit p101 or p84/p87, is activated by G-protein-coupled receptors without affecting BCR signaling [14]. PI3K $\gamma$ plays an important role in the immune system and is involved in inflammation [15].
The pan-PI3K inhibitors such as LY294002, which inhibit all PI3K classes [16], have not been successful in clinical development, mainly because of their toxic effects and poor pharmacokinetic properties [17]. In aggressive refractory MCL, in which $\mathrm{p} 110 \alpha$ and $\mathrm{p} 110 \delta$ are most likely to be involved in BCR signaling [11], the efficacy of these inhibitors has not been well defined.

In this study, we investigated the role of class IA PI3Ka and $\mathrm{PI} 3 \mathrm{~K} \delta$ isoforms on proliferation of aggressive MCL cells via constitutive activation of the PI3K/Akt pathway utilizing PI3K isoform-specific inhibitors. Our results indicate that both $\mathrm{p} 110 \alpha$ and $\mathrm{p} 110 \delta$ are involved in ligandindependent PI3K/Akt activation.

\section{Materials and Methods}

\section{Reagents}

The pan-PI3K inhibitor LY294002, p110a-selective inhibitor designated PI3Ka inhibitor IV \{3-[4-morpholinothieno(3,2-D) pyrimidin-2-yl]phenol dihydrochloride $\}$, and $110 \beta$-selective inhibitor TGX-221 were purchased from Calbiochem (San Diego, Calif., USA). The selective inhibitor of p110 $\gamma$ AS-605240 was obtained from Sigma-Aldrich (St. Louis, Mo., USA), and the p110 $\delta$-selective inhibitor IC87114 was from Symansis (Auckland, New Zealand). The class I PI3K-specific inhibitor GDC0941 was obtained from Genentech Inc. (San Francisco, Calif., USA).

\section{Cell Lines and Culture Conditions}

Three MCL cell lines, Granta 519 [18], JVM-2 [19], and Jeko-1 [20], were used in this study. Granta 519 and JVM-2 express wildtype (wt) $p 53$, while Jeko- 1 is mutant for $p 53$ (loss of $p 53$ expression) [20]. JVM-2 and Jeko-1 cells were cultured in RPMI 1640 medium containing $15 \%$ fetal bovine serum (FBS) and $1 \%$ penicillin/streptomycin, while Granta 519 was grown in Dulbecco's modified Eagle's medium supplemented with 15\% FBS and 1\% penicillin/streptomycin. Primary MCL samples were obtained after informed consent in accordance with institutional guidelines set forth by Aichi Medical University and Saga University per Declaration of Helsinki principles. Mononuclear cells were purified by Ficoll-Hypaque (Sigma-Aldrich) density gradient centrifugation, and nonadherent cell were resuspended in RPMI 1640 medium supplemented with $10 \%$ FBS at a density of $6 \times 10^{6}$ cells $/ \mathrm{ml}$. Clinical characteristics of the patients are summarized in online supplementary table 1 (for all online suppl. material, see www.karger. com/doi/10.1159/000353164).

For cell viability assays, Western blot, and cell cycle analysis, cells were first acclimated in RPMI 1640 or Dulbecco's modified Eagle's medium containing 5\% FBS for $16 \mathrm{~h}$ prior to exposure to inhibitors. Control cells were treated with an equivalent amount of DMSO under the same growth conditions.

Cell Viability/Proliferation Assay

Cell viability was assessed by the trypan blue dye exclusion method, and cell proliferation was determined by the CellTiter 96 AQueous One Solution Cell Proliferation Assay (MTS; Promega,
Tabe/Jin/Konopleva/Shikami/Kimura/ Andreeff/Raffeld/Miida 
Madison, Wisc., USA) according to the company's protocol. Optical density was measured using a SpectraMax 340PC (Molecular Devices, Sunnyvale, Calif., USA).

\section{Apoptosis and Cell Cycle Analysis}

Apoptotic cell death was analyzed by annexin $\mathrm{V}$ staining with fluorescein isothiocyanate-conjugated annexin V (Roche Diagnostics, Indianapolis, Ind., USA) and propidium iodide (PI) [21]. The extent of drug-specific apoptosis was assessed by the formula: percent specific apoptosis $=($ test - control $) \times 100 /(100-$ control $)$. Cell cycle distribution was analyzed by flow-cytometric analysis of PIstained nuclei [21]. Annexin V fluorescence or PI-stained DNA content was determined by a FACScan flow cytometer (Becton Dickinson Immunocytometry Systems, San Jose, Calif., USA). Flow-cytometric data were analyzed by CellQuest software (Becton Dickinson). Gating was set to exclude cell debris, cell doublets, and cell clumps.

\section{Western Blot Analysis}

Total cell lysates were collected as described elsewhere [5]. Total protein $(30 \mu \mathrm{g})$ was separated by SDS polyacrylamide gel electrophoresis (Bio-Rad Laboratories, Hercules, Calif., USA), transferred to polyvinylidene fluoride membranes, and then probed with primary and secondary antibodies according to the manufacturers' protocols. For immunoblotting, the following antibodies were used: $\alpha$-tubulin (Sigma-Aldrich), p110 (EMD Millipore, Billerica, Mass., USA), p110a, p110 $\beta$, p110 $\gamma$, phosphorylated (p)-Akt ${ }^{\mathrm{Ser}^{473}}$, $\mathrm{p}-\mathrm{Akt}^{\mathrm{Thr}}{ }^{308}, \mathrm{p}^{-\mathrm{Rb}^{\mathrm{Ser}}{ }^{780}}$, cyclin D1, p-GSK3 $\beta^{\mathrm{Ser}^{9}}, \mathrm{p}-\mathrm{S} 6 \mathrm{~K}^{\mathrm{Ser}^{240 / 244}}$, p-4E-BP1 $1^{\mathrm{Thr}^{3}{ }^{3 / 46}}, \mathrm{p}-\mathrm{mTOR}^{\mathrm{Ser}^{2448}}$, and horseradish peroxidaselinked anti-mouse and anti-rabbit IgG (all from Cell Signaling Technology, Beverly, Mass., USA).

Small Interfering RNA Transfection

PI3K p110 gene expression was silenced by small interfering RNA (siRNA) using Stealth RNAi (Invitrogen, Carlsbad, Calif., USA). The sense strand of the siRNA silencing (p110 $\delta$-siRNA) was UCUUAAAGAUGAUGCCCACGCUGCC (NM_005026.3, 2522-2546), UCAUGAUGUUGUCGCUGUGCCGAUC (NM_ 005026.3, 2885-2909), and UACUGGAUGUCUUUGGAGCAGCUGA (NM_005026.3, 3174-3198).

As a nonspecific control, a Stealth RNAi siRNA Negative Control Med GC (Invitrogen) was used. Transfection was facilitated by the Lipofectamine RNAiMAX transfection reagent (Invitrogen) following the manufacturer's instructions. Gene silencing was verified by Western blot performed $48 \mathrm{~h}$ after transfection.

\section{Results}

\section{PI3K Isoforms Are Expressed in MCL Cells}

To establish the baseline status of the pathway, we first assessed the expression levels of PI3K isoforms in the MCL cell lines Jeko-1, JVM-2, and Granta 519. Western blot analysis revealed that the tested cells expressed p110a, p110 $\beta$, and p110 (fig. 1), which was consistent with a previous report that leukocytes usually contain all three class IA PI3K subclasses [9]. The expression level of p110a was higher in Jeko-1 and JVM-2 than in Granta 519. The

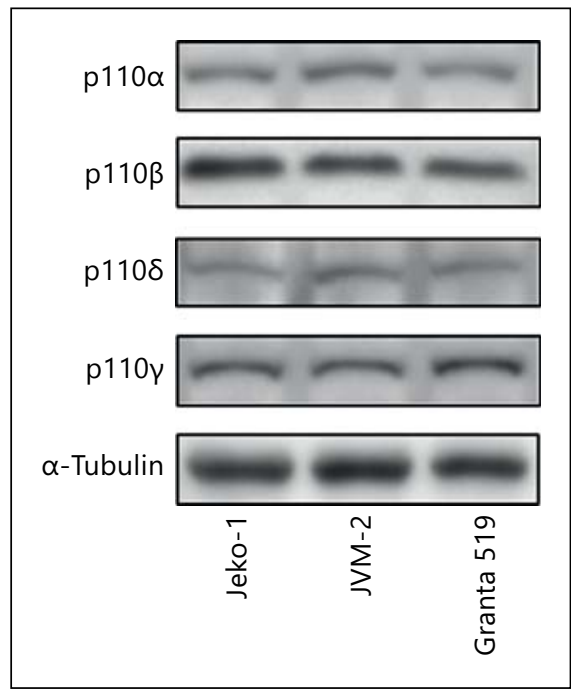

Fig. 1. Expression levels of PI3K isoforms in MCL cells. Expression levels of PI3K isoforms were assessed in untreated MCL cells by Western blot. Representative results from 3 independent experiments are shown.

tested MCL cell lines demonstrated similar intermediate expression levels of $\mathrm{p} 110 \delta$. The MCL cells also expressed class IB p110 $\gamma$.

\section{Inhibition of PI3Ka Induces Cell Cycle Arrest in MCL Cells}

We next assessed the effects of various PI3K inhibitors on MCL cell cycle progression and apoptosis. As shown in figure 2, treatment with PI3Ka inhibitor IV or nonspecific PI3K inhibitor LY294002 impeded cell cycle progression, with accumulation of cells in the $G_{0} / G_{1}$ phase and depression of the $\mathrm{S}$-phase fraction, in a dose-dependent manner. PI3Ka inhibitor IV $(5 \mu \mathrm{M})$ increased the $\mathrm{G}_{0} / \mathrm{G}_{1}$ fraction by a mean of $29.1 \pm 4.2 \%$ for Jeko- $1,12.2 \pm 3.6 \%$ for JVM2, and $20.3 \pm 3.2 \%$ for Granta 519 compared to the same fraction in control cells. LY294002 $(5 \mu \mathrm{M})$ increased the $\mathrm{G}_{0} / \mathrm{G}_{1}$ fraction by a mean of $14.8 \pm 2.4,13.3 \pm 2.5$ and $16.5 \pm 3.4 \%$ for Jeko- 1 , JVM2, and Granta 519, respectively, compared to the same fraction in controls. Although recent reports raise the possibility that the 53 status could affect the blocking of PI3K/Akt/mTOR signaling by PI3K inhibitors $[5,22]$, no significant differences in the sensitivity to specific PI3K isoform inhibitors was observed between wt p53-expressing cells (JVM-2 and Granta 519) and p53-mutant cells (Jeko-1). On the contrary, no increases in the $G_{0} / G_{1}$ fraction were detected in cells treated with IC87114, TGX115, or AS-605240 (fig. 2). While PI3Ka inhibitor IV and LY294002 exhibited dose-depen- 


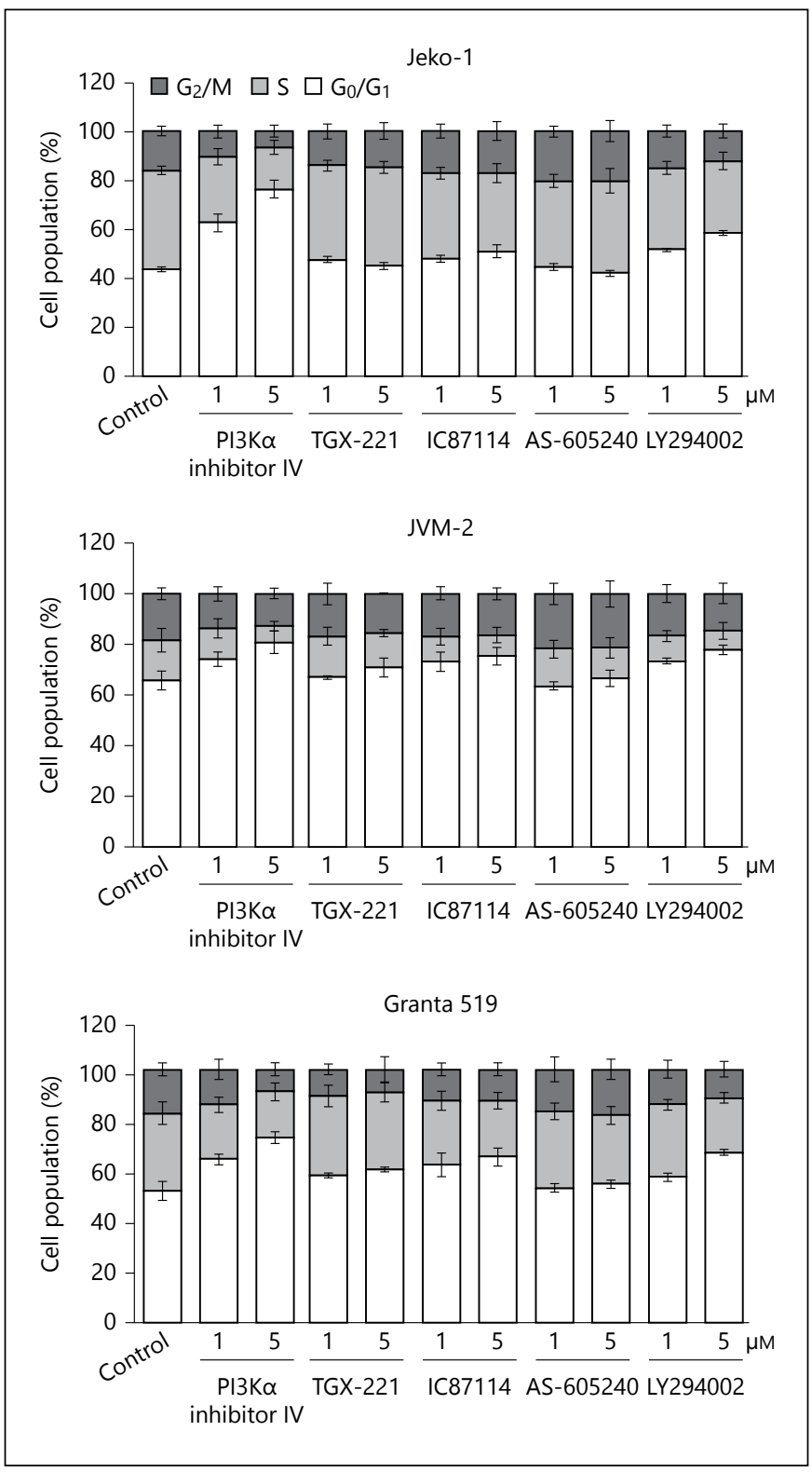

Fig. 2. Effects of PI3K isoform-specific inhibitors on cell cycle in MCL cells. Jeko-1, JVM-2, and Granta 519 cells were treated with 1 or $5 \mu \mathrm{M}$ of PI3Ka inhibitor IV, TGX-221, AS-605240, IC87114, or LY294002 for $48 \mathrm{~h}$ and processed for flow-cytometric analysis by PI staining. Graphs represent average percentages of cell populations in each cell cycle phase $( \pm$ SEM) from 3 independent experiments.

dent cell growth-inhibitory activity in the tested cells as assessed by the MTS assay ( $\mathrm{IC}_{50}$ at $48 \mathrm{~h}$ : PI3Ka inhibitor IV, $10.7 \mu \mathrm{M}$ for Jeko-1, $3.2 \mu \mathrm{M}$ for JVM2, and $9.3 \mu \mathrm{M}$ for Granta 519; LY294002, 8.1 $\mu \mathrm{M}$ for Jeko-1, $7.4 \mu \mathrm{M}$ for JVM2, and $9.4 \mu \mathrm{M}$ for Granta 519), IC87114 induced moderate inhibition of cell growth (fig. 3a). Treatment with PI3Ka inhibitor IV or LY294002 reduced cell viability as demonstrated by concentration-dependent increases in the percentage of trypan blue-positive cells (fig. 3b). We have confirmed induction of apoptotic cell death using annexin $\mathrm{V}$ flow cytometry in Jeko-1 cells (fig. 3c).

\section{PI3K $\alpha$ and PI3K $\delta$ Inhibit the PI3K/Akt/mTOR Pathway and Downregulate Cell Cycle-Related Proteins}

To assess the inhibitory efficacy of PI3Ka inhibitor IV on the PI3K/Akt/mTOR pathway, we performed Western blot analysis of p-Akt and mTOR downstream target p-S6K, two markers of PI3K/Akt/mTOR signaling activation [17]. In all tested MCL cell lines, p-Akt and p-S6K were clearly expressed at baseline and fully inhibited following treatment with PI3Ka inhibitor IV (fig. 4a). To exclude the possibility that PI3K/Akt signaling was activated by growth factors present in the serum [5], we confirmed the constitutive activation of Akt after 24 and $48 \mathrm{~h}$ of conditioning in serum-free medium, and the nonspecific PI3K inhibitor LY294002 also inhibited expression of p-Akt and its downstream targets (data not shown). The p110 $\delta$ inhibitor IC87114 downregulated p-Akt and p-S6K in Jeko- 1 and Granta 519 cells but to a lesser extent than PI3Ka inhibitor IV (fig. 4a). To investigate the molecular basis underlying cell cycle arrest by PI3Ka inhibitor IV, we evaluated the expression of several cell cycleregulatory proteins. The high expression levels of cyclin D1 were downregulated by PI3Ka inhibitor IV, and substantial decreases in $\mathrm{Rb}$ phosphorylation were also detected. Levels of GSK-3 $\beta$ kinase, a direct downstream target of Akt that has been shown to negatively regulate cell cycle progression through cyclin D1 repression in MCL cells [4], were decreased by PI3Ka inhibitor IV in a concentration-dependent manner. Likewise, levels of $4 \mathrm{E}$ $\mathrm{BP} 1$, a downstream target of mTOR known to enhance cyclin D1 translation, were also decreased by PI3Ka inhibitor IV. Treatment with IC87114 induced moderate decrease in p-Akt, p-S6K, and p-4E-BP1 levels in both Jeko- 1 and Granta 519 cells, while no significant change in p-GSK-3 $\beta$, cyclin D1, or p-Rb was observed. The phosphorylation of forkhead transcription factor/forkhead box O3a, another positive regulator of cyclin D1, showed no significant changes in response to PI3Ka inhibitor IV or IC87114 (data not shown).

To assure the specificity of the observed cellular effects upon PI3K pharmacological inhibition, we evaluated the consequences of siRNA-mediated silencing of p $110 \delta$ in Granta 519 cells. siRNA against $\mathrm{p} 110 \delta$ caused downregulation not only of p110 $\delta$ but also its regulatory partner 


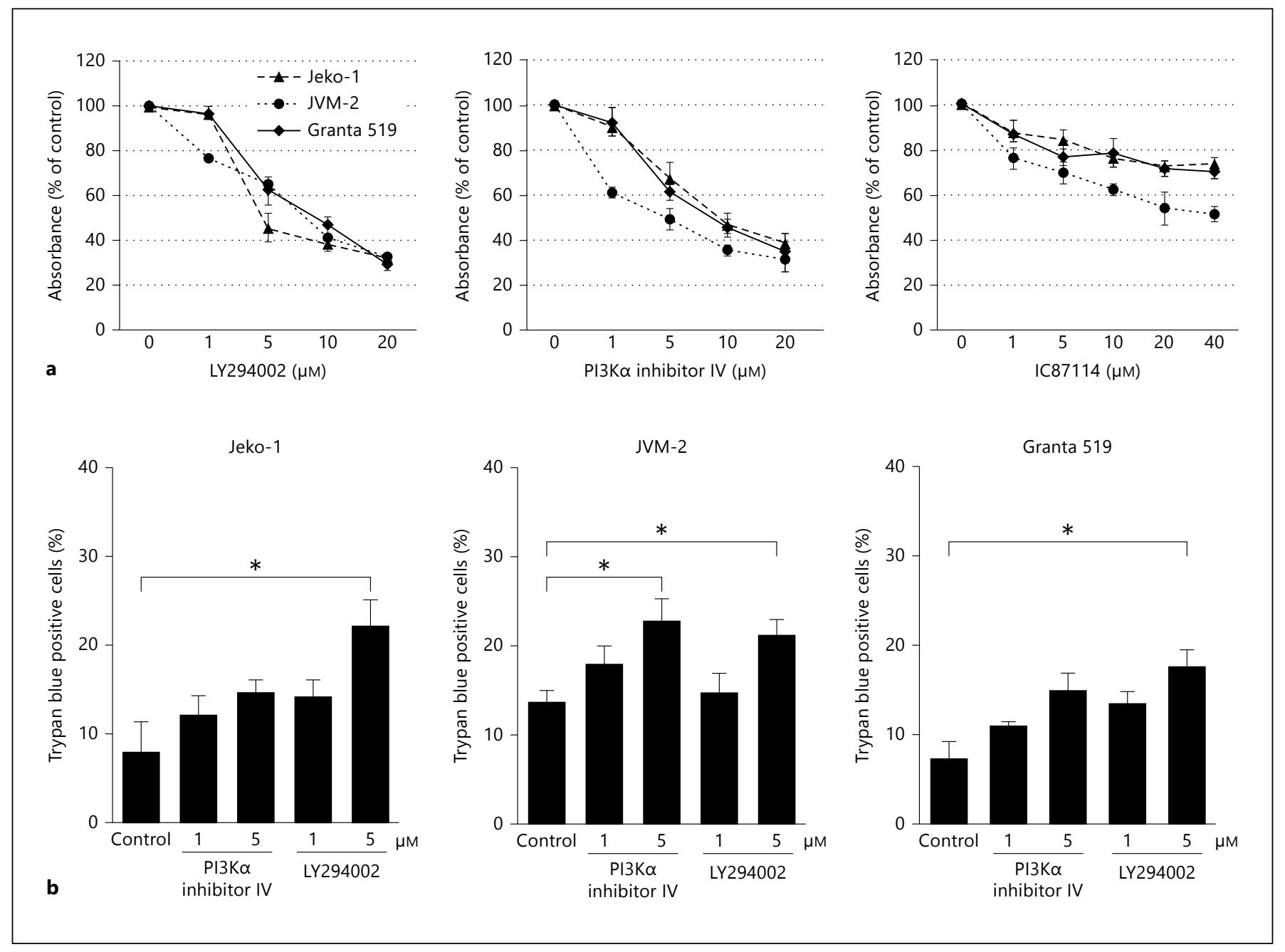

Fig. 3. Effects of PI3K isoform-specific inhibitors on cell viability in MCL cells. Jeko-1, JVM-2, and Granta 519 cells were treated with the indicated doses of PI3Ka inhibitor IV, IC87114, or LY294002 for 48 h. a Inhibition of cell proliferation was deter-

p85 along with considerable decreased expression of other PI3K isoforms (p110a, p110 $\beta$, and p110 $\gamma$; online suppl. fig. 1), consistent with published findings in glioma cells [23]. Furthermore, p110 $\delta$ siRNA completely abrogated Akt phosphorylation which was only partially diminished by IC87114. These results suggest that genetic disruption of a specific PI3K isoform, unlike pharmacological inhibitors, may affect other important components of PI3K/ Akt signaling.

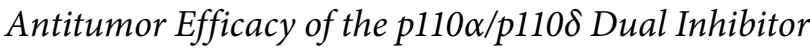 GDC-0941 in MCL Cells}

We next investigated MCL cell responsiveness to the concomitant inhibition of $\mathrm{p} 110 \alpha / \mathrm{p} 110 \delta$ by the novel mined by MTS assay. b Cytotoxic effects were detected by trypan blue staining. Graphs at the top represent FACS data, while the bar graphs represent average percentages \pm SEMs from 3 independent experiments. ${ }^{*} \mathrm{p}<0.05,{ }^{* *} \mathrm{p}<0.01$.

class I PI3K-selective inhibitor GDC-0941 [24]. The potency of GDC-0941 against phosphorylated protein biomarkers of the PI3K pathway p-Akt and its downstream target $\mathrm{p}$-GSK3 $\beta$ has been confirmed by Western blot analysis (fig. 5a). We next monitored viability of MCL cells treated with GDC-0941. GDC-0941 at submicromolar concentrations caused significant cell growth inhibition, substantiating higher activity compared to PI3Ka inhibitor IV or IC87114 (IC 50 at $48 \mathrm{~h}: 0.2 \mu \mathrm{M}$ for Jeko-1, $0.3 \mu \mathrm{M}$ for JVM-2, and $0.8 \mu \mathrm{M}$ for Granta 519; fig. 5b). This was associated with an increase in trypan blue-positive dead cells (fig. 5c) and accumulation of cells in the $G_{0} / G_{1}$ phase with corresponding depletion of proliferating cells with S-phase DNA content (fig. 5d). 

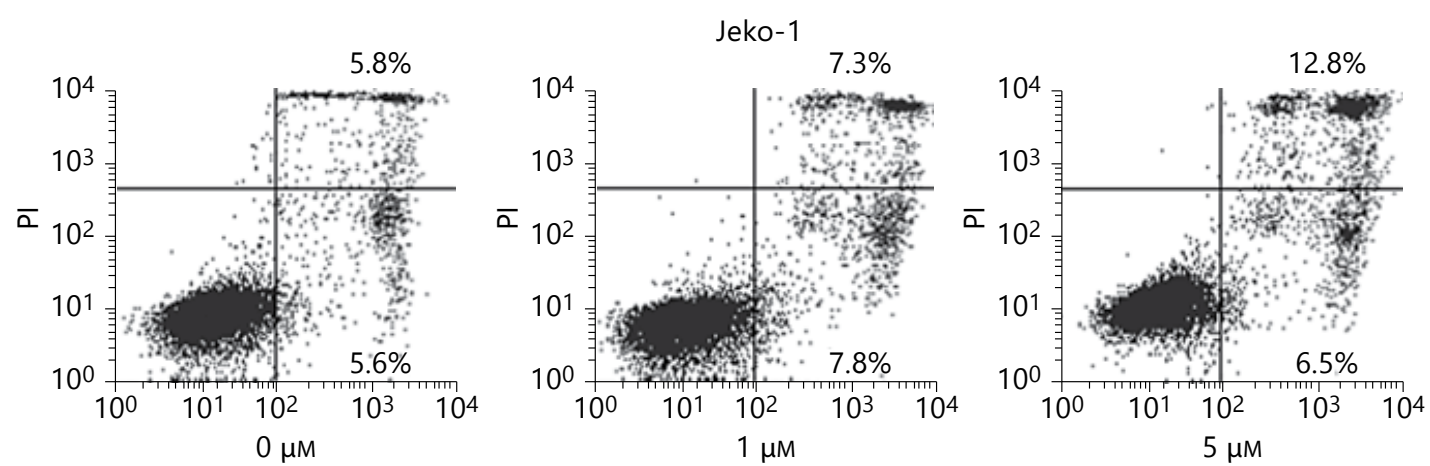

$\mathrm{PI} 3 \mathrm{~K} \alpha$ inhibitor IV

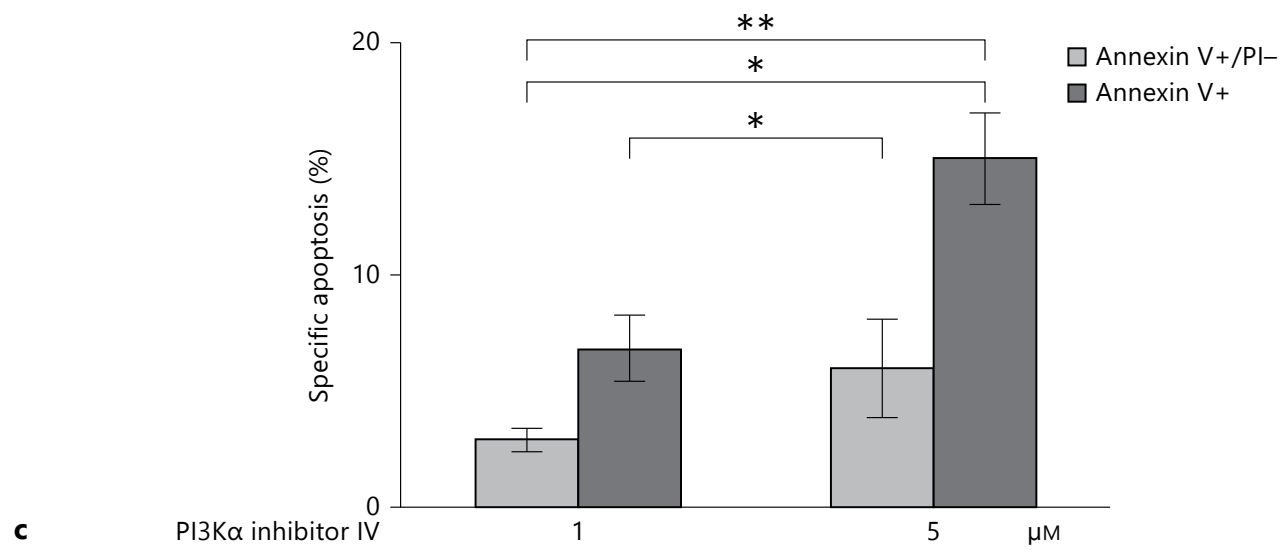

Fig. 3. Effects of PI3K isoform-specific inhibitors on cell viability in MCL cells. Jeko-1, JVM-2, and Granta 519 cells were treated with the indicated doses of PI3Ka inhibitor IV, IC87114, or LY294002 for 48 h. c Apoptosis induction was measured by flow-

We also utilized cells from two primary MCL patients (online suppl. table 1) to assess the antiproliferative effects of p110a inhibition by PI3Ka inhibitor IV, p110 inhibition by IC87114, or dual p110a/p110 $\delta$ inhibition by GDC-0941. GDC-0941 treatment induced more prominent cell growth inhibition and increase in trypan blue-positive dead cells than PI3Ka inhibitor IV or IC87114 in both samples (fig. 6).

\section{Discussion}

Our findings show that the growth of MCL cell lines with constitutive activation of PI3K/Akt/mTOR signaling was attenuated by inhibition of the PI3K p110a isoform, and that this growth inhibition was related primar- cytometric analysis with annexin V/PI staining. Graphs at the top represent FACS data, while the bar graphs represent average percentages \pm SEMs from 3 independent experiments. ${ }^{*} p<0.05$, ** $\mathrm{p}<0.01$.

ily to $G_{0} / G_{1}$ cell cycle arrest and moderate apoptotic responses. In our system, treatment of MCL cells with the p110 $\delta$-specific inhibitor IC87114 resulted in limited growth inhibition, with moderate downregulation of $\mathrm{p}$ Akt, p-S6K, and p-4E-BP1, and almost no change in p-GSK-3 $\beta$, cyclin D1, or $\mathrm{p}-\mathrm{Rb}$ levels compared to the more robust inhibition seen with the p110a PI3Ka inhibitor IV. In turn, dual inhibition of p110a and p1 $10 \delta$ by GDC-0941 caused more prominent cell growth inhibition compared to the single isoform-targeted inhibitors.

Several reports have implicated the PI3Ka isoform in PI3K/Akt oncogenic activation in B-cell lymphoma/leukemia, including MCL $[25,26]$. In MCL cells, a frequent gain of PIK3CA gene copy number, but not activating mutations of the PIK3CA gene, has been shown to contribute to oncogenic activation of the PI3K/Akt pathway
64

Acta Haematol 2014;131:59-69 DOI: $10.1159 / 000353164$
Tabe/Jin/Konopleva/Shikami/Kimura/ Andreeff/Raffeld/Miida 

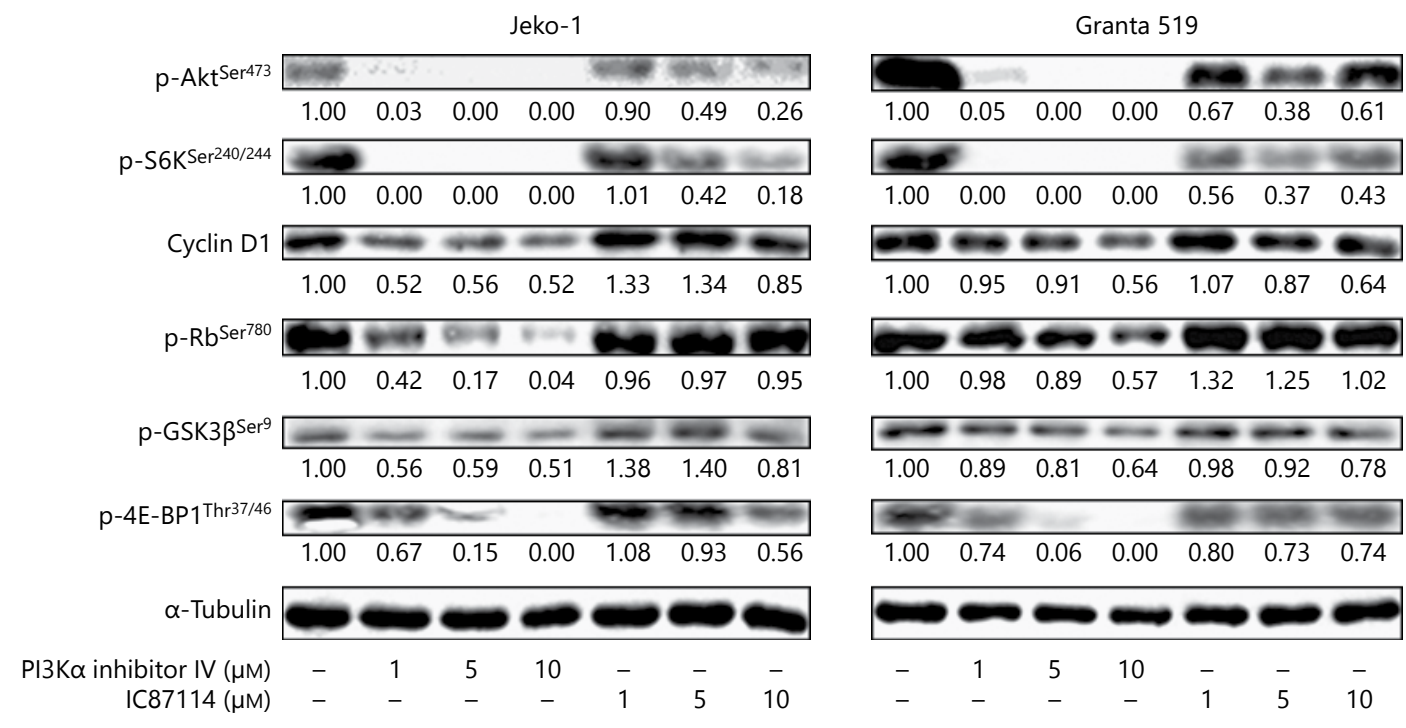

Fig. 4. Western blot analysis of PI3K/Akt/mTOR signaling and cell cycle-related proteins. Jeko-1 and Granta 519 cells were treated with the indicated dose of PI3Ka inhibitor IV or IC87114 for $24 \mathrm{~h}$, subjected to lysis, and analyzed by Western blot. Changes in the expression levels of $\mathrm{p}-\mathrm{Akt}^{\mathrm{Ser}^{473}}, \mathrm{p}-\mathrm{S} 6 \mathrm{~K}^{\mathrm{Ser}{ }^{240 / 244}}$, cyclin D1, $\mathrm{p}-\mathrm{Rb}^{\mathrm{Ser} \mathrm{r}^{780}}$,

[26]. Whereas $\mathrm{p} 110 \alpha$ and $\mathrm{p} 110 \delta$ inhibitors have reproducible inhibitory effects on the viability of chronic lymphoid leukemia (CLL) cells and on Akt phosphorylation, the p110a effects were notably stronger than the p110 effects [25]. On the other hand, the p110 $\delta$ isoform is known to play a critical role in BCR signaling [27] and is indispensable for BCR-induced DNA synthesis and activation of $\mathrm{PI} 3 \mathrm{~K} / \mathrm{Akt} / \mathrm{mTOR}$ signaling [28]. A previous study reported that the $110 \delta$ inhibitor CAL-101, an orally active derivative of IC87114, promoted apoptosis in primary CLL cells in which Akt phosphorylation is dependent on CD40 ligation and stromal contact [29]. These findings suggest that the prosurvival effects of PI3K activation in B-cell malignancies are mediated through the combined activation of $\mathrm{p} 110 \mathrm{a}$ and $\mathrm{p} 110 \delta$, with higher dependency upon p110a [25].

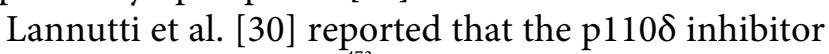
CAL-101 blocked $\mathrm{Akt}^{\mathrm{Ser} 73}$ phosphorylation in patientderived MCL cells following BCR crosslinking and in Jeko- 1 cells upon activation of CXCR5, CXCR4, BCR, or BAFF (B-cell-activating factor belonging to the TNF family), but these investigators did not report the effects on cell growth. In our study, though we did observe mild inhibition of growth of all tested MCL cells following treatment with IC87114, this PI3K $\delta$ inhibitor was not

PI3K Inhibition in Mantle Cell Lymphoma
p-GSK3 $\beta^{\text {Ser }^{9}}$ and $\mathrm{p}-4 \mathrm{E}-\mathrm{BP} 1^{\mathrm{Th} r^{37 / 46}}$ are shown. Intensity of the immunoblot signals after background subtraction was quantified using ImageJ software, and the relative intensity compared with that of a-tubulin was calculated. Representative results from 3 independent experiments are shown.

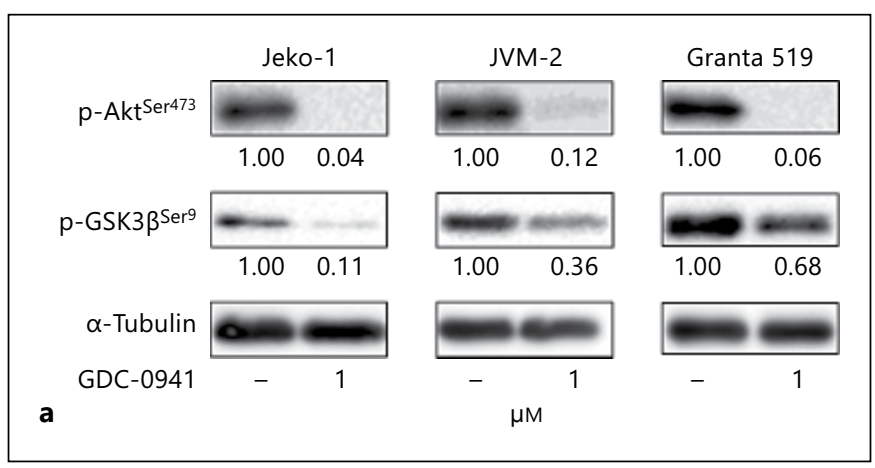

Fig. 5. Effects of the p110 $\alpha$ and $p 110 \delta$ dual inhibitor GDC-0941 in MCL cells. a Jeko-1, JVM-2, and Granta 519 cells were treated with GDC-0941 $(1 \mu \mathrm{M})$ for $24 \mathrm{~h}$, subjected to lysis, and analyzed by Western blot. Changes in the expression levels of $\mathrm{p}-\mathrm{Akt}^{\mathrm{Ser}^{43}}$ and p-GSK $3 \beta^{\text {Ser }^{9}}$ are shown. Intensity of the immunoblot signals after background subtraction was quantified using ImageJ software, and the relative intensity compared with that of $\alpha$-tubulin was calculated. Representative results from 3 independent experiments are shown.

nearly as effective in inhibiting cell growth as was the PI3Ka inhibitor IV. At difference with small-molecule inhibitors, silencing of p110 $\beta$ by siRNA completely diminished Akt phosphorylation, but this was likely caused by concomitant alterations in its regulatory part- 

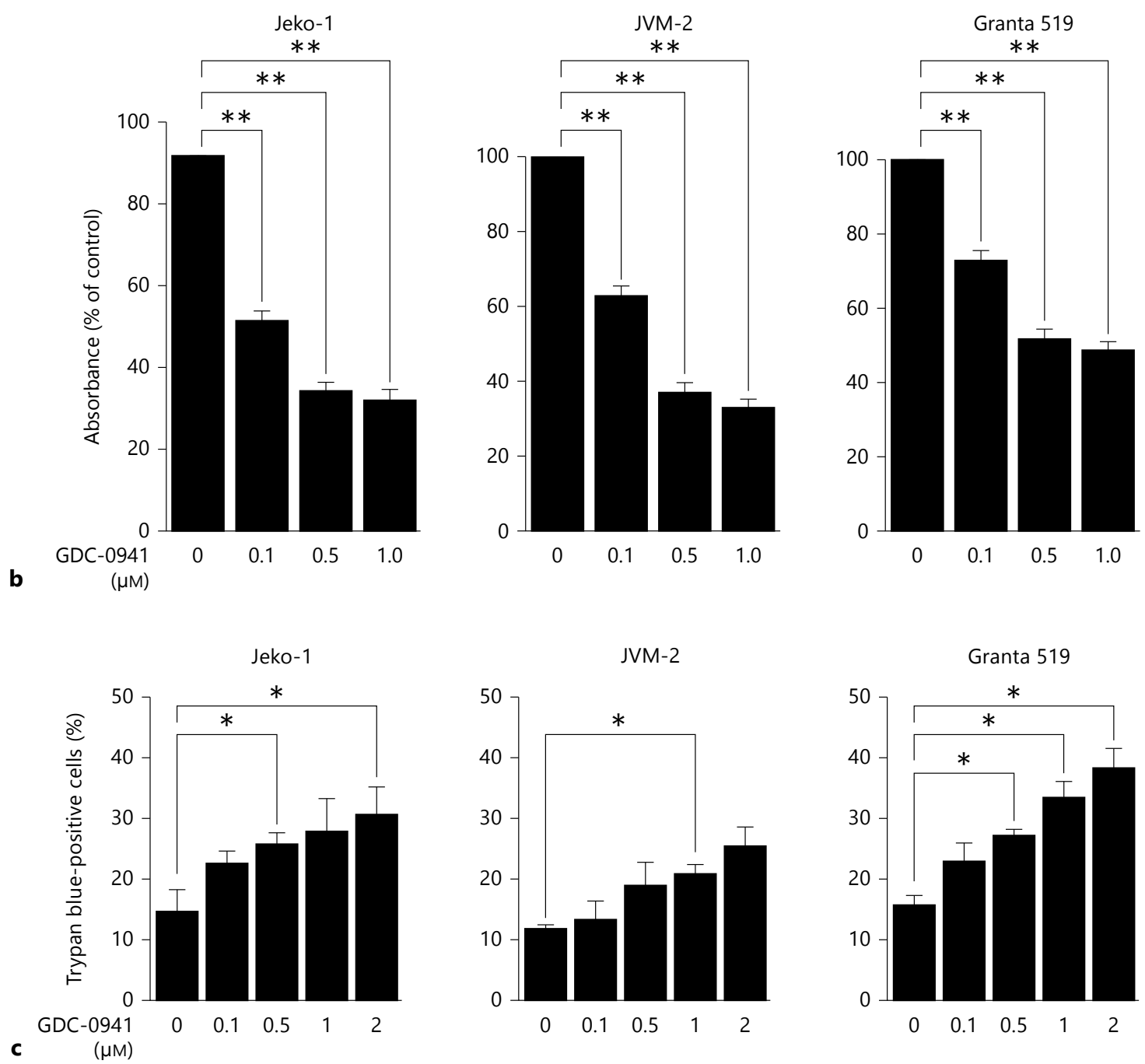

Fig. 5. Effects of the p110 a and p110 $\delta$ dual inhibitor GDC-0941 in MCL cells. b-d Jeko-1, JVM2, and Granta 519 cells were treated with the indicated doses of GDC0941 for $48 \mathrm{~h}$. After treatment, inhibition of cell proliferation was determined by MTS assay (b), cytotoxic effects were detected trypan blue staining (c), and induction of cell cycle arrest was measured by flow-cytometric analysis by PI staining (d). Graphs represent average percentages \pm SEMs from 3 independent experiments. ${ }^{*} \mathrm{p}<0.05$, ** $\mathrm{p}<0.01$.

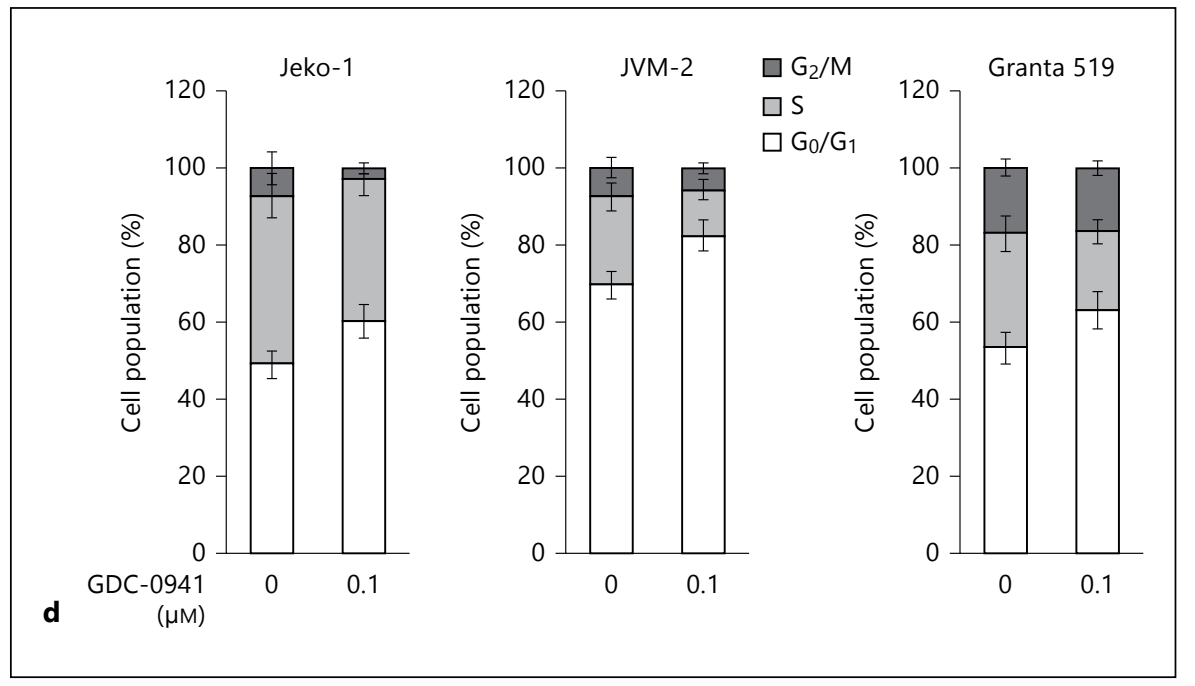

Tabe/Jin/Konopleva/Shikami/Kimura/ Andreeff/Raffeld/Miida 
Fig. 6. Effects of PI3K isoform-specific inhibitors in primary MCL cells. Primary MCL cells were incubated for $48 \mathrm{~h}$ with PI3Ka inhibitor IV, IC87114, or GDC0941. Clinical characteristics of patients 1 (a) and 2 (b) are summarized in the online supplementary table 1 . Viable cell number was measured by trypan blue exclusion.

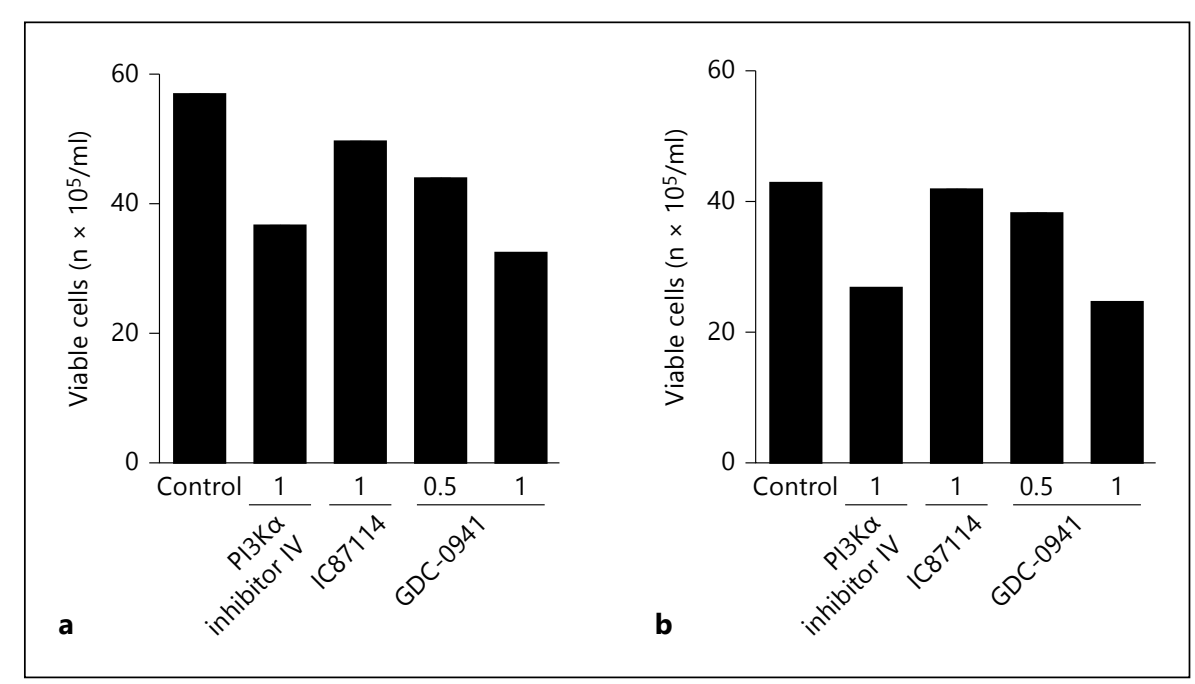

ner p85 and decreased expression of other PI3K isoforms, highlighting previously reported discrepancies between RNA interference and small-molecule PI3K isoform inhibitors [23, 31]. Notably, Lannutti et al. [30] observed no constitutive activation of Akt at the phosphorylation residue of $\mathrm{Ser}^{473}$ in MCL cells that they studied, whereas we found constitutive $\mathrm{Akt}^{\mathrm{Ser}{ }^{473}}$ phosphorylation in MCL cell lines and in a subset of MCL cases [5]. It is known that B cells utilize both p110a and p1 $10 \delta$ and that these have overlapping functions at various stages of development [11]. It is possible that agonist-independent constitutive BCR/PI3K/Akt signaling activation in aggressive MCL cells and cell lines [32] is less dependent on $110 \delta$ than the signaling occurring following BCR ligand or cytokine activation in CLL or classic MCL. Our study differed from that of Lannutti et al. [30] by focusing on activation of agonist-independent constitutive BCR/PI3K/Akt signaling without BCR crosslinking or chemokine/cytokine activation. Granta 519 has amplification of the PIK3CA gene [25] and Jeko1 has amplification of the $S Y K$ gene upstream of PI3K [33]. The amplification or constitutive activation through an upstream activator might be a reason for the increased sensitivity to the p110a inhibitors. Herman et al. [29] further demonstrated the effects of p110 $\delta$ inhibition, which may disrupt the protection of CLL cells by stromal cells through diminishing production of B-cellactivating factors TNF- $\alpha, \mathrm{CD} 40 \mathrm{~L}$, and fibronectin by stromal cells. Chronic active BCR signaling has been implicated as a new pathogenetic mechanism, suggesting the possibility of novel therapeutic strategies [10] and that the effects of p $110 \delta$ inhibition within the microen- vironment of MCL cells, which we did not investigate in this study, could be indispensable to such therapeutic strategies.

Recently, novel PI3K isoform-specific inhibitors have been developed as potential chemotherapeutic drugs and have entered clinical trials [17]. Dual inhibition of p110a and $\mathrm{p} 110 \delta$ by GDC-0941 translated into more pronounced antitumor effects compared to selective p110a or p110 $\delta$ inhibitors in both MCL cell lines and MCL primary samples. These results indicate that simultaneous inhibition of $\mathrm{p} 110 \mathrm{\alpha}$ and $\mathrm{p} 110 \delta$ by small-molecular inhibitors might be a useful strategy to block survival signals in $\mathrm{B}$-cell malignancies that depend on active BCR tonic signaling $[11,34]$ and on microenvironment-mediated prosurvival signaling.

Several negative regulators of Akt and mTOR prosurvival pathways, including AMPK $\beta 1$, TSC2, and PTEN, appear to be novel stress-related transcriptional targets of p53 [22]. Our results suggest, however, that the antiproliferative effects of PI3K inhibition were not strengthened by wt p53 expression. This finding is concordant with a recent report indicating that Akt inhibitors are capable of inducing apoptosis in CLL cells irrespective of the TP53 status [35].

In conclusion, our results provide evidence that the specific inhibition of class IA PI3Ks, including p $110 \alpha$ and p110 $\delta$, may contribute to abrogation of the constitutive Akt activation and cell proliferation in aggressive MCL; they also suggest that selective inhibition of these isoforms may be a promising therapeutic approach against the aggressive blastoid variants of MCL. 


\section{Acknowledgments}

The authors wish to thank Hiroko Iwanami, Tomomi Ikeda, Takako Ikegami, Akemi Koyanagi, and Tamami Sakanishi for technical assistance, and Dr. Masao Seto for kindly providing the Jeko1 cells. We acknowledge the support of the Laboratories of Molecular and Biochemical Research and Cell Biology, Research Sup- port Center, Juntendo University Graduate School of Medicine for use of facilities. We are grateful to Kathryn Hale for her review and Melodie England for her help in the preparation of the paper.

This work was supported in part by the Institute for Environmental and Gender-specific Medicine, Juntendo University, and by the Project Research Program of the Juntendo University School of Medicine (to Y.T.).

\section{References}

$\checkmark 1$ Jares P, Colomer D, Campo E: Genetic and molecular pathogenesis of mantle cell lymphoma: perspectives for new targeted therapeutics. Nat Rev Cancer 2007;7:750-762.

-2 Quintanilla-Martinez L, Davies-Hill T, Fend F, Calzada-Wack J, Sorbara L, Campo E, Jaffe ES, Raffeld M: Sequestration of p27Kip1 protein by cyclin D1 in typical and blastic variants of mantle cell lymphoma (MCL): implications for pathogenesis. Blood 2003;101: 3181-3187.

3 Bodrug SE, Warner BJ, Bath ML, Lindeman GJ, Harris AW, Adams JM: Cyclin D1 transgene impedes lymphocyte maturation and collaborates in lymphomagenesis with the myc gene. EMBO J 1994;13:2124-2130.

4 Dal Col J, Zancai P, Terrin L, Guidoboni M, Ponzoni M, Pavan A, Spina M, Bergamin S, Rizzo S, Tirelli U, De Rossi A, Doglioni C, Dolcetti R: Distinct functional significance of Akt and mTOR constitutive activation in mantle cell lymphoma. Blood 2008;111:5142-5151.

5 Rudelius M, Pittaluga S, Nishizuka S, Pham

- TH, Fend F, Jaffe ES, Quintanilla-Martinez L, Raffeld M: Constitutive activation of Akt contributes to the pathogenesis and survival of mantle cell lymphoma. Blood 2006;108:16681676.

6 6 Hess G, Herbrecht R, Romaguera J, Verhoef G, Crump M, Gisselbrecht C, Laurell A, Offner F, Strahs A, Berkenblit A, Hanushevsky O, Clancy J, Hewes B, Moore L, Coiffier B: Phase III study to evaluate temsirolimus compared with investigator's choice therapy for the treatment of relapsed or refractory mantle cell lymphoma. J Clin Oncol 2009;27: 3822-3829.

7 Vivanco I, Sawyers CL: The phosphatidylinositol 3-kinase AKT pathway in human cancer. Nat Rev Cancer 2002;2:489-501.

$\checkmark 8$ Rodriguez-Viciana $\mathrm{P}$, Warne $\mathrm{PH}$, Dhand R, Vanhaesebroeck B, Gout I, Fry MJ, Waterfield MD, Downward J: Phosphatidylinositol$3-\mathrm{OH}$ kinase as a direct target of Ras. Nature 1994;370:527-532.

-9 Vanhaesebroeck B, Welham MJ, Kotani K, Stein R, Warne PH, Zvelebil MJ, Higashi K, Volinia S, Downward J, Waterfield MD: P110delta, a novel phosphoinositide 3-kinase in leukocytes. Proc Natl Acad Sci USA 1997; 94:4330-4335.

10 Davis RE, Ngo VN, Lenz G, Tolar P, Young RM, Romesser PB, Kohlhammer H, Lamy L, Zhao H, Yang Y, Xu W, Shaffer AL, Wright G,
Xiao W, Powell J, Jiang JK, Thomas CJ, Rosenwald A, Ott G, Muller-Hermelink HK, Gascoyne RD, Connors JM, Johnson NA, Rimsza LM, Campo E, Jaffe ES, Wilson WH, Delabie J, Smeland EB, Fisher RI, Braziel RM, Tubbs RR, Cook JR, Weisenburger DD, Chan WC, Pierce SK, Staudt LM: Chronic active B-cellreceptor signalling in diffuse large B-cell lymphoma. Nature 2010;463:88-92.

-11 Ramadani F, Bolland DJ, Garcon F, Emery JL, Vanhaesebroeck B, Corcoran AE, Okkenhaug K: The PI3K isoforms p110alpha and p110delta are essential for pre-B cell receptor signaling and B cell development. Sci Signal 2010; 3:ra60.

$\checkmark 12$ Samuels Y, Wang Z, Bardelli A, Silliman N, Ptak J, Szabo S, Yan H, Gazdar A, Powell SM, Riggins GJ, Willson JK, Markowitz S, Kinzler KW, Vogelstein B, Velculescu VE: High frequency of mutations of the PIK3CA gene in human cancers. Science 2004;304:554.

13 Jia S, Liu Z, Zhang S, Liu P, Zhang L, Lee SH, Zhang J, Signoretti S, Loda M, Roberts TM, Zhao JJ: Essential roles of PI(3)K-p110beta in cell growth, metabolism and tumorigenesis. Nature 2008;454:776-779.

14 Rommel C, Camps M, Ji H: PI3K delta and PI3K gamma: partners in crime in inflammation in rheumatoid arthritis and beyond? Nat Rev Immunol 2007;7:191-201.

15 Del Prete A, Vermi W, Dander E, Otero K, Barberis L, Luini W, Bernasconi S, Sironi M, Santoro A, Garlanda C, Facchetti F, Wymann MP, Vecchi A, Hirsch E, Mantovani A, Sozzani S: Defective dendritic cell migration and activation of adaptive immunity in PI3Kgamma-deficient mice. EMBO J 2004;23:35053515.

16 Hu L, Zaloudek C, Mills GB, Gray J, Jaffe RB: In vivo and in vitro ovarian carcinoma growth inhibition by a phosphatidylinositol 3-kinase inhibitor (LY294002). Clin Cancer Res 2000; 6:880-886.

17 Kong D, Yamori T: Advances in development of phosphatidylinositol 3-kinase inhibitors. Curr Med Chem 2009;16:2839-2854.

18 Jadayel DM, Lukas J, Nacheva E, Bartkova J, Stranks G, De Schouwer PJ, Lens D, Bartek J, Dyer MJ, Kruger AR, Catovsky D: Potential role for concurrent abnormalities of the cyclin D1, p16CDKN2 and p15CDKN2B genes in certain B cell non-Hodgkin's lymphomas. Functional studies in a cell line (Granta 519). Leukemia 1997;11:64-72.
19 Melo JV, Brito-Babapulle V, Foroni L, Robinson DS, Luzzatto L, Catovsky D: Two new cell lines from B-prolymphocytic leukaemia: characterization by morphology, immunological markers, karyotype and Ig gene rearrangement. Int J Cancer 1986;38:531-538.

20 Jeon HJ, Kim CW, Yoshino T, Akagi T: Establishment and characterization of a mantle cell lymphoma cell line. Br J Haematol 1998;102: 1323-1326.

21 Tabe Y, Konopleva M, Munsell MF, Marini FC, Zompetta C, McQueen T, Tsao T, Zhao S, Pierce S, Igari J, Estey EH, Andreeff M: PMLRARalpha is associated with leptin-receptor induction: the role of mesenchymal stem cellderived adipocytes in APL cell survival. Blood 2004;103:1815-1822.

22 Feng Z, Hu W, de Stanchina E, Teresky AK, Jin S, Lowe $S$, Levine AJ: The regulation of AMPK beta1, TSC2, and PTEN expression by p53: stress, cell and tissue specificity, and the role of these gene products in modulating the IGF-1-AKT-mTOR pathways. Cancer Res 2007;67:3043-3053.

23 Fan QW, Knight ZA, Goldenberg DD, Yu W, Mostov KE, Stokoe D, Shokat KM, Weiss WA: A dual PI3 kinase/mTOR inhibitor reveals emergent efficacy in glioma. Cancer Cell 2006;9:341-349.

24 Folkes AJ, Ahmadi K, Alderton WK, Alix S, Baker SJ, Box B, Chuckowree IS, Clarke PA, Depledge P, Eccles SA, Friedman LS, Hayes A, Hancox TC, Kugendradas A, Lensun L, Moore P, Olivero AG, Pang J, Patel S, PerglWilson GH, Raynaud FI, Robson A, Saghir N, Salphati L, Sohal S, Ultsch MH, Valenti M, Wallweber HJ, Wan NC, Wiesmann C, Workman P, Zhyvoloup A, Zvelebil MJ, Shuttleworth SJ: The identification of 2-(1H-indazol-4-yl)-6-(4-methanesulfonyl-piperazin1-ylmethyl)-4-morpholin-4-yl-thieno [3,2-d] pyrimidine (GDC-0941) as a potent, selective, orally bioavailable inhibitor of class I PI3 kinase for the treatment of cancer. J Med Chem 2008;51:5522-5532.

25 Niedermeier M, Hennessy BT, Knight ZA, Henneberg M, Hu J, Kurtova AV, Wierda WG, Keating MJ, Shokat KM, Burger JA: Isoform-selective phosphoinositide $3^{\prime}$-kinase inhibitors inhibit CXCR4 signaling and overcome stromal cell-mediated drug resistance in chronic lymphocytic leukemia: a novel therapeutic approach. Blood 2009;113:5549_ 5557. 
26 Psyrri A, Papageorgiou S, Liakata E, Scorilas A, Rontogianni D, Kontos CK, Argyriou P, Pectasides D, Harhalakis N, Pappa V, Kolialexi A, Economopoulou C, Kontsioti F, Maratou E, Dimitriadis G, Economopoulou P, Economopoulos T: Phosphatidylinositol $3^{\prime}$-kinase catalytic subunit alpha gene amplification contributes to the pathogenesis of mantle cell lymphoma. Clin Cancer Res 2009; 15:5724-5732.

-27 Jou ST, Carpino N, Takahashi Y, Piekorz R, Chao JR, Wang D, Ihle JN: Essential, nonredundant role for the phosphoinositide 3-kinase p110delta in signaling by the B-cell receptor complex. Mol Cell Biol 2002;22:85808591.

28 Bilancio A, Okkenhaug K, Camps M, Emery JL, Ruckle T, Rommel C, Vanhaesebroeck B: Key role of the p110delta isoform of PI3K in $\mathrm{B}$-cell antigen and IL-4 receptor signaling: comparative analysis of genetic and pharmacologic interference with p110delta function in B cells. Blood 2006;107:642-650.
29 Herman SE, Gordon AL, Wagner AJ, Heerema NA, Zhao W, Flynn JM, Jones J, Andritsos L, Puri KD, Lannutti BJ, Giese NA, Zhang X, Wei L, Byrd JC, Johnson AJ: Phosphatidylinositol 3-kinase-delta inhibitor CAL-101 shows promising preclinical activity in chronic lymphocytic leukemia by antagonizing intrinsic and extrinsic cellular survival signals. Blood 2010;116:2078-2088.

30 Lannutti BJ, Meadows SA, Herman SE, Kashishian A, Steiner B, Johnson AJ, Byrd JC, Tyner JW, Loriaux MM, Deininger M, Druker BJ, Puri KD, Ulrich RG, Giese NA: CAL101, a p110delta selective phosphatidylinositol-3-kinase inhibitor for the treatment of Bcell malignancies, inhibits PI3K signaling and cellular viability. Blood 2011;117:591-594.

31 Weiss WA, Taylor SS, Shokat KM: Recognizing and exploiting differences between RNA and small-molecule inhibitors. Nat Chem Biol 2007;3:739-744.
32 Gururajan M, Jennings CD, Bondada S: Cutting edge: constitutive $B$ cell receptor signaling is critical for basal growth of B lymphoma. J Immunol 2006; 176:5715-5719.

33 Rinaldi A, Kwee I, Taborelli M, Largo C, Uccella S, Martin V, Poretti G, Gaidano G, Calabrese G, Martinelli G, Baldini L, Pruneri G, Capella C, Zucca E, Cotter FE, Cigudosa JC, Catapano CV, Tibiletti MG, Bertoni F: Genomic and expression profiling identifies the B-cell associated tyrosine kinase Syk as a possible therapeutic target in mantle cell lymphoma. Br J Haematol 2006;132:303316.

34 Limon JJ, Fruman DA: B cell receptor signaling: picky about PI3Ks. Sci Signal 2010;3: pe 25 .

35 de Frias M, Iglesias-Serret D, Cosialls AM, Coll-Mulet L, Santidrian AF, Gonzalez-Girones DM, de la Banda E, Pons G, Gil J: Akt inhibitors induce apoptosis in chronic lymphocytic leukemia cells. Haematologica 2009; 94:1698-1707. 